\title{
An Empirical Test of the Export-Led Model in the Member Countries of the Andean Community (Comunidad Andina de Naciones-CAN)
}

Alexander Carvajal and Oscar David Andrés Julián López Camargo 


\section{An Empirical Test of the Export-Led Model in the Member Countries of the Andean Community (Comunidad Andina de Naciones-CAN)}

Abstract: This paper seeks to empirically test the applicability of the export-led model to the economies of the countries belonging to the Andean Community (Comunidad Andina de Naciones-CAN) by verifying the export-led growth (ELG) bypothesis, which indicates that gross domestic product (GDP) behavior is based on export (EXP) dynamics. This hypothesis was tested for Bolivia, Colombia, Ecuador, and Peru. The methodology used was the application of Johansen cointegration and Block Exogeneity Wald tests to identify Granger causality between variables of the natural logarithms of EXP and GDP. The results obtained show that the causal effect of exports on GDP can only be rejected for the Bolivian economy. Lastly, the main conclusion of this study is that the economic policies of the CAN member countries should not assume that the export sectors are the foundations of their respective economies. Therefore, the CAN governments should not introduce economic policies that prioritize the expansion of the export sector.

Keywords: Export-led; Andean Community; exports; Gross Domestic Product; regional economy; economic policies; Johansen cointegration; Block. Exogeneity Wald tests; export sector.

JEL Classification: F02, C13, C20, C32.

\section{Contrastación empírica del modelo Export-Led en los países miembros de la Comunidad Andina de Naciones (CAN)}

Resumen: Este escrito buscó contrastar empiricamente la aplicabilidad del modelo Export-Led enlas economias de los paises pertenecientes a la Comunidad Andina de Naciones CAN, mediante laverificación de la hipótesis de crecimiento Export-led ELG, la cual indica que el producto internobruto PIB basa su comportamiento por la dinámica de las exportaciones EXP, lo anterior se probópara Bolivia, Colombia, Ecuador y Perú. La metodología empleada fue la aplicación de las pruebasde cointegración de Johansen y exogeneidad por bloques de Wald, utilizadas para identificar laGrangercausalidad entre las variables logaritmo natural de EXP y logaritmo natural de PIB. Losresultados obtenidos muestran que solamente en la economía boliviana no se puede rechazar quelas Exportaciones causan el Producto Interno Bruto. Finalmente, se ha indicado, como principalconclusión, que las politicas económicas de los países miembros de la CAN no deben partir deconsiderar el sector exportador como el sector básico de la economía y por ello, el Estado de cadapaís, no debe intervenir con políticas económicas que prioricen la expansión del sector exportador.

Palabras clave: Impulso a las exportaciones; Comunidad Andina; exportaciones; producto interno bruto; economía regional; políticas económicas; cointegranción de Johansen; test de exogeneidad en bloque de Wald; sector exportador.

\section{(cc) BY-NC-SA}

Este artículo y sus anexos se distribuyen por la revista Lecturas de Economía bajo los términos de la Licencia Creative Commons Atribución-NoComercial-CompartirIgual 4.0. https://creativecommons.org/licenses/by-nc-sa/4.0/ 
Test empirique du modèle axé sur l'exportation dans les pays membres de la Communauté andine des nations (CAN)

Résumé: Ce document vise à tester empiriquement l'applicabilité du modèle axé sur l'exportation aux économies des pays appartenant à la Communauté andine (CAN) en vérifiant l'bypothèse de la croissance tirée par les exportations (ELG), qui indique que le comportement du produit intérieur brut (PIB) est soutenu par la dynamique des exportations (EXP). Cette hypothèse a été mise en contraste pour la Bolivie, la Colombie, l'Équateur et le Pérou. La méthodologie utilisée a été l'application des tests de cointégration Johansen et d'exogénéité du type Wald pour identifier la causalité de Granger entre les variables logarithmiques naturelles de l'EXP et du PIB. Les résultats obtenus montrent que l'effet causal des exportations sur le PIB ne peutêtre rejeté que pour l'économie bolivienne. Enfin, la principale conclusion de cette étude est que les politiques économiques des pays membres de la CAN ne doivent pas partir du principe que les secteurs d'exportation sont le fondement de leurs économies respectives. Par conséquent, les gouvernements de la CAN ne devraient pas intégrer des politiques économiques qui donnent la priorité à l'expansion du secteur de l'exportation.

Mots clés: Promotion des exportations; Communauté andine; exportations; produit intérieur brut; économie régionale; politiques économiques; co-intégration de Johansen; test d'exogénéité du type Wald; secteur des exportations.

Cómo citar / How to cite this item:

Carvajal, A. \& López, O. (2021). An Empirical Test of the Export-Led Model in the Member Countries of the Andean Community (Comunidad Andina de Naciones-CAN). Lecturas de Economia, 94, 267-282.

https://doi.org/10.17533/udea.le.n94a343336 


\title{
An Empirical Test of the Export-Led Model in the Member Countries of the Andean Community (Comunidad Andina de Naciones-CAN)
}

\author{
Alexander Carvajal $\oplus^{\mathrm{a}}$ and Oscar David Andrés Julián López \\ Camargo ${ }^{\mathrm{b}}$
}

-Introduction. -I. Materials and Methods. -II. Results. -III. Discussion. -References

Original manuscript received 06 August 2020; final version accepted 06 November 2020

\section{Introduction}

The export-led model states that exports are the basis for growth in a region's production levels, and therefore, promoting the export sector should be an economic policy priority to improve economic indicators such as gross domestic product (GDP), thereby improving employment levels and economic stability. Moreover, the Andean Community (Comunidad Andina de Naciones-CAN) countries have experienced an average per capita GDP growth (in current dollars) of 7\% annually from 1970-2010 (Comunidad Andina de Naciones, 2010, p. 1), which reveals growth in production in these countries. This makes it possible to ask whether the export-led model's economic growth hypothesis has been realized in the economies of the CAN countries. To respond affirmatively to this question implies that the economic policies of Bolivia, Colombia, Ecuador, and Peru (the current CAN members) should revolve around "the expansion of markets for local production and the attraction of new investment for the basic industry sector through instruments such as promotion and information programs, and direct and indirect subsidies for investors" (Gaviria Ríos, 2010, p. 1).

a Alexander Carvajal: Professor and researcher in the Faculty of International Business. Universidad Santo Tomás, Colombia. Email: alexander.carvajal@usantoto.edu.co https://orcid.org/0000-0003-0627-366X

b Oscar David Andrés Julián López. Camargo: Professor and researcher in the Faculty of International Business. Universidad Santo Tomás, Colombia. Email: oscar.lopezc@usantoto.edu.co https://orcid.org/0000-0002-9905-6498 
Carvajal and López Camargo An Empirical Test of the Export-Led Model in the Member...

A study titled "How stable is the export-led growth hypothesis? Evidence from Asia's Four Little Dragons" focuses on the economies of Hong Kong, South Korea, Singapore, and Taiwan. In general, the study proposes two econometric models to establish the veracity of the export-led model. The first model relates the natural logarithm of GDP with the natural logarithm of exports, while the second model includes the natural logarithm of the real exchange rate as the second independent variable. The study applies the modified Wald causality test (MWald) and the rolling regression technique to establish whether there is causality between EXP and GDP. The results obtained are not constant throughout the period studied, nor are they constant among the four economies analysed. Therefore, we cannot conclude with certainty that the export-led hypothesis is valid. This aligns with the main recommendation made by Tang et al. (2015):

"for the four economies to re-assess their growth strategies which are overly dependent on exports to developed countries. However, these four economies cannot completely discard their export-oriented policies given that their domestic markets are relatively small. New policy strategies aimed at diversifying export markets through regional integration should be implemented immediately" (p. 235).

Another study ${ }^{1}$ on this subject is "The Export-Led Growth: A Case Study of Costa Rica," in which Johansen cointegration and Granger tests are conducted to establish long-term causality between EXP and GDP. The results obtained for the period 1980-2013 reveal that "exports and real GDP of Costa Rica have a long-run relationship and there is a unidirectional causal relationship from economic growth to export" (Gokmenoglu et al., 2015, p. 476); therefore, the level of exports is not a variable that can explain economic growth. Yet another example is "The role of export composition in export-led growth in Australia and its regions." In this study, the exportled growth hypothesis is tested through a sectoral (agriculture, mining, fuels, manufacturing, and others) study of exports and their relationship with GDP at the national and regional levels. The authors, Shafiullah et al. (2017),

1 There is ample literature on the subject; however, the only studies mentioned are those with methodologies similar to the one presented here. 
conclude that "ELG (Export Led Growth) is validated in Australia in the long-run. In addition to being 'Mining and Fuels'-led, ELG is seen to be led nationally by Agriculture, Manufacturing, and Other exports in Australia. Among the regions, the growth path is found to be unique for each region based on the causality tests and long-run equation estimations" (p. 71). The contradictory conclusions of these studies do not allow us to settle on the notion that the growth hypothesis proposed by the export-led model is entirely valid.

At their 1989 Galapagos meeting, the CAN countries developed a strategic design and work plan to create a new model that would replace the import substitution model, and "with this model, the Andean countries eliminated tariffs among themselves and formed a free trade zone in 1993 in which goods could flow freely" (Comunidad Andina de Naciones, 2018). This article is grounded on a hypothesis that is based on accepting the fact that the increase in trade among the CAN countries has generated higher EXP growth for Bolivia, Colombia, Ecuador, and Peru. However, the behaviour of the EXP variable is not believed to explain the behaviour of the GDP variable during the post-1990 period. Namely, this study seeks to prove that the export-led model is not valid for the CAN, so its main objective is to empirically test the applicability of the export-led model in the economies of the countries belonging to the Andean Community. Acceptance of the proposed hypothesis implies questioning the application of economic policies based on export promotion as a driving force for economic growth.

\section{Materials and Methods}

The methodology applied in this study is based on the work of Tang et al. (2015) and can be summarised as follows:

1. Creation of a regression model that represents the causality relation between EXP and GDP, as established in the export-led model.

2. Cointegration test between EXP and GDP.

3. Block Exogeneity Wald test.

These steps are described in detail in the following section. 
Carvajal and López Camargo An Empirical Test of the Export-Led Model in the Member...

\section{A. Export-Led Model}

The export-led model is a Keynesian approach that is a variant of the Hoyt model, which was developed in the 1950s by Charles Tiebout and Douglas North: "They replace the physical variables of Hoyt's model with aggregate macroeconomic variables - income, demand internal and external to the region - to determine the economic growth of areas rather than their physical development" (Gaviria Ríos, 2010, p. 1). The model is based on the Keynesian demand equation and assumes that public expenditure $(G)$ and taxes $(\mathrm{T})$ are zero $(G$ and $T=0)$, giving:

$$
Y=C+X-M
$$

Where:

$$
\begin{aligned}
& Y: \text { Revenue - income } \\
& C: \text { Consumption } \\
& X: \text { Exports } \\
& M: \text { Imports } \\
& \text { and with: }
\end{aligned}
$$

$$
\begin{aligned}
C & =c Y \\
X & =\bar{X} \\
M & =m Y
\end{aligned}
$$

with $\bar{X}$ as an exogenous variable, so that $0<c<1$ y $0<m<1$. Substituting this in Equation 1 renders:

$$
Y=\frac{1}{1-(c-m)} \bar{X}
$$

with

$$
0<c-m<1
$$

"where $\frac{1}{1-(c-m)}$ is the traditional Keynesian multiplier and $(c-m)$ is the marginal propensity to consume goods produced within the economy" 
(Gaviria Ríos, 2010, p. 14). Equation 2 clearly shows that income is a multiple of exports.

Therefore, in alignment with the theory presented above, the following model is proposed.

$$
\ln \left(P I B_{t}\right)=\beta_{1}+\beta_{2} \ln \left(E X P_{t}\right)+\mu_{t}
$$

It is assumed that the model's residuals are distributed normally and are white noise. All the data for the model were obtained from the CEPALSTAT integrated database of the Economic Commission for Latin America and the Caribbean (ECLAC), except for the data for the real export variable obtained from the World Integrated Trade Solution (WITS) system of the World Bank (WB).

For the GDP variable, annual real GDP data were used (base $=2010$ ), and quarterly data were estimated according to the quarterly percentage calculated using the database for the quarterly gross domestic product, by the class of economic activity at current prices. The EXP variable was obtained as annual data of real EXP (base $=2010$ ), and quarterly data were also estimated according to the quarterly percentage calculated from the quarterly balance of payments database. The data for the two variables (stated in millions of U.S. dollars) are expressed in natural logarithm form.

Per the availability of information and the estimates made, the data for each country were 1. Bolivia - quarterly data from the first quarter of 1993 to the last quarter of 2016; 2. Colombia - quarterly data from the first quarter of 2000 to the last quarter of 2016; 3. Ecuador - quarterly data from the first quarter of 1993 to the last quarter of 2016; and 4. Peru - quarterly data from the first quarter of 1994 to the last quarter of 2016.

\section{B. Cointegration Test}

Cointegration is "the property in which two or more time-series share a common stochastic trend” (Sant'Anna, Filomena \& Caldeira, 2017, p. 149). Cointegration makes it possible to solve the typical time series problem of creating a relationship model between variables (for example, a simple 
Carvajal and López Camargo An Empirical Test of the Export-Led Model in the Member...

regression) that turn out to be spurious. For cointegration to exist, the following must be true. First, the variables must be stationary $I(1)$. Second, the residuals of a linear combination must be of order $0(I(0))$. Engle and Granger (1987) argue that:

"in a regression of the type $y=a+b . x+\mu, \widehat{\mu}$ is stationary $I(0)$ so $\hat{b}$ is not only consistent but is super-consistent (that is, the estimate converges to its real value in inverse proportion to the number of observations, instead of to the quadratic root of the number of observations, as is the case for stationary variables)" (Montero, 2013, p. 6).

This implies that to test cointegration, it is necessary to perform stationarity tests. As such, this study conducted the augmented DickeyFuller (ADF) and the Kwiatkowski-Phillips-Schmidt-Shin (KPSS) tests. This is based on the validation conducted by Schlitzer (1995) using Monte Carlo methods, which stated, "The results show that, although at the cost of producing a large number of inconclusive answers, the combined procedure allows us to consistently reduce the number of incorrect conclusions" (p. 142).

The cointegration test conducted was the Johansen test since "Johansen's procedure performs better than single-equation methods and multivariate ones, even when the errors are not normally distributed or when the dynamics are unknown and we over-parameterize by including additional lags in the Error-Correction Model (ECM)" (Gonzalo, 1994, p. 225). As such, the ECM vector is estimated using the Enders (2003) equation:

$$
\Delta Z_{t}=\Phi D_{t}+\Pi Z_{t-1}+\sum_{i=1}^{k-1} \Gamma_{i} \Delta Z_{t-i}+\mu_{t}
$$

with

$$
\Gamma_{i}=-\sum_{j=i+1}^{p} A_{j}
$$

where $\Delta Z_{t}$ represents the first differences of endogenous variables vectors $\ln \left(P I B_{t}\right)$ and $\ln \left(E X P_{t}\right) ; \Phi D_{t}$ represents the matrix of parameters of the 
deterministic vector, $\Pi$ represents the information matrix on the long-term relationship between the variables of vector $Z_{t}$; and $A_{i}$ represents the matrix of fixed coefficients. The test used the trace statistic and the statistic of the largest proper value; the null hypotheses established refer to the number of cointegration vectors $(\mathrm{r})$.

\section{Block Exogeneity Wald Test}

According to Enders (2003), this test detects whether the lags of one variable can Granger-cause another variable; the statistical test is thus defined:

$$
(T-3 p-1)\left(\log \left|\Sigma_{r e}\right|-\log \left|\Sigma_{u n}\right|\right) \sim \chi^{2}(2 p)
$$

This equation is explained by (Nguyen, 2011), who states:

" $T$ is the number of observations; $\Sigma_{u n}$ are variance/covariance matrices of the unrestricted VAR system; $\Sigma_{r e}$ are variance/covariance matrices of the restricted system when the lag of a variable is excluded from the VAR system, and $p$ is the number of lags of the variable that is excluded from the VAR system" (p. 6).

The null hypothesis of this test states that a dependent variable is not the Granger cause of an independent variable. According to Granger (1969), the concept of Granger causality can be summarised as follows: a dependent variable $Y$ is caused by an independent $X$ if the lags in the latter contribute to the estimation of the current values of $Y$ (Granger, 1969).

In the proposed model, the cointegration tests of the $\ln (G D)$ and $\ln (E X P)$ variables were performed for all the countries studied. The Block Exogeneity Wald test was performed for the countries in which stationarity was found; these results are presented in the following section.

\section{Results}

Table 1 presents the results of the estimation of the model proposed in Equation 3. For all countries, the model displays the following:

- at 5\%, individual significance for the slope and the intercept ( $t$ statistic) 
Carvajal and López Camargo An Empirical Test of the Export-Led Model in the Member...

- at 5\%, global significance ( $F$ statistic)

- a high value for the coefficient of determination $R^{2}$

Table 1. Results of the simple linear regression model estimation

\begin{tabular}{lcccccc}
\hline Country & Intercept & $\boldsymbol{t}$ statistic & Slope & $\boldsymbol{t}$ statistic & $\boldsymbol{F}$ statistic & $\boldsymbol{R}^{\mathbf{2}}$ \\
\hline Bolivia & 3.54 & 19.01 & 0.65 & 25.6 & 655.36 & 0.87 \\
Colombia & 3.43 & 8.59 & 0.82 & 19.2 & 367.48 & 0.84 \\
Ecuador & 2.65 & 8.71 & 0.83 & 22.8 & 521.01 & 0.84 \\
Peru & 3.77 & 12.6 & 0.73 & 21.6 & 468.32 & 0.84 \\
\hline
\end{tabular}

Source: Own elaboration.

As discussed in the previous section, the results presented in Table 1 can be spurious, so Tables 2 and 3 establish the existence of cointegration between the $\ln (G D P)$ and $\ln (E X P)$ variables.

Table 2. Results of the ADF and KPSS stationarity tests

\begin{tabular}{lcccccccc}
\hline \multirow{2}{*}{ Country } & \multicolumn{2}{c}{ ADF } & \multicolumn{2}{c}{ KPSS } & \multicolumn{2}{c}{ ADF } & \multicolumn{2}{c}{ KPSS } \\
\cline { 2 - 9 } & $\ln G D P$ & $\ln E X P$ & $\ln G D P$ & $\ln E X P$ & $\Delta \ln G D P$ & $\Delta \ln E X P$ & $\Delta \ln G D P$ & $\Delta \ln E X P$ \\
\hline Bolivia & $0.92(5)$ & $0.83(8)$ & $2.46(3)^{* * *}$ & $2.42(3)^{* * *}$ & $-3.23(4)^{* * *}$ & $-3.09(7)^{* * *}$ & $0.32(3)$ & $0.19(3)$ \\
Colombia & $-0.04(0)$ & $-0.12(3)$ & $1.78(3)^{* * *}$ & $1.68(3)^{* * *}$ & $-3.21(10)^{* * *}$ & $-6.01(5)^{* * *}$ & $0.14(3)$ & $0.03(3)$ \\
Ecuador & $0.03(1)$ & $-1.08(6)$ & $2.45(3)^{* * *}$ & $2.35(3)^{* * *}$ & $-8.06(0)^{* * *}$ & $-6.89(5)^{* * *}$ & $0.11(3)$ & $0.02(3)$ \\
Peru & $0.02(10)$ & $-2.12(6)$ & $2.37(3)^{* * *}$ & $2.31(3)^{* * *}$ & $-1.28(11)$ & $-5.82(5)^{* * *}$ & $0.17(3)$ & $0.11(3)$ \\
\hline
\end{tabular}

Note: The asterisks indicate the rejection of the null hypothesis of the respective test (at 5\%). The numbers in parentheses indicate the lag order in each test.

Source: Own elaboration.

According to Gabriel (2010), the null hypotheses of the ADF and KPSS stationarity tests refer to:

1. ADF test: The series has a unit root, which is the same as saying that it is not stationary; and

2. KPSS test: The series is stationary. 
The ADF test was estimated with a constant due to the possibility that the series mean did not assume a value of zero, "although the null hypothesis is one with a unit root, but without drift - Case 2 of Hamilton" (Regúlez, 2006, p. 2).

Table 2 shows that for Bolivia, Colombia and Ecuador, the variables studied are stationary $I(1)$. For Peru, it is not possible to be certain of the rejection of the presence of the unit root because the ADF test for the first differences in the $\ln (G D P)$ variable did not allow rejection of the null hypothesis.

Table 3. Results of the Johansen Cointegration Tests

\begin{tabular}{lcccc}
\hline Country & $\begin{array}{c}\text { Lag order of VAR } \\
\text { (stationary series })\end{array}$ & Null Hypothesis & Trace Statistic & $\begin{array}{c}\text { Largest proper } \\
\text { value statistic } \\
\lambda-\text { max }\end{array}$ \\
\hline Bolivia & 4 & Cointegration range 0 & $24.6^{* * *}$ & $23.8^{* * *}$ \\
Colombia & 1 & Cointegration range 1 & 0.76 & 0.76 \\
& \multirow{2}{*}{1} & Cointegration range 0 & $30.16^{* * *}$ & $30.16^{* * *}$ \\
Ecuador & \multirow{2}{*}{$\begin{array}{c}\text { Cointegration range 1 } \\
\text { Peru }\end{array}$} & Cointegration range 0 & 0.002 & 0.002 \\
& & Cointegration range 1 & 0.0012 & $29.6^{* * *}$ \\
& & Cointegration range 0 & 12.1 & 0.0012 \\
\hline
\end{tabular}

Note: The asterisks indicate the rejection of the null hypothesis of the respective test (at 5\%) and per the critical values (15.41 and 3.76) presented by Osterwald-Lenum (1992).

Source: Own elaboration.

In Table 3 , the value of the lag order of $V A R(p)$ was determined by the minimum values of the (Schwartz) Bayesian information criterion (BIC) and the Hannan-Quinn information criterion (HQC). The estimate was made with an unrestricted constant. The results of the trace and largest proper value statistics show that for Bolivia, Colombia, and Ecuador, the null hypothesis for no cointegration is rejected, and the null hypothesis for cointegration range 1 is not rejected. 
Carvajal and López Camargo An Empirical Test of the Export-Led Model in the Member...

In the case of Peru, the null hypothesis for no cointegration cannot be rejected. Added to the $\mathrm{ADF}$ test result for the first differences of $\ln (G D P)$, this does not guarantee (for Peru) the presence of cointegration for the established variables. Therefore, the causality test for this country was not conducted. One must remember that the stationarity and cointegration test results are needed before the causality assessment is conducted (Jaunky, 2013).

Table 4. Results of the Block Exogeneity Wald test

\begin{tabular}{lccc}
\hline Country & $\begin{array}{c}\text { Lag order of VAR } \\
\text { (stationary series) }\end{array}$ & Null Hypothesis & $\begin{array}{c}\text { Statistic for VAR } \\
\text { Granger Causality / } \\
\text { Block Exogeneity } \\
\text { Wald tests }\end{array}$ \\
\hline Bolivia & 4 & Exports do not 'Granger-cause' GDP & $13.2^{* * *}$ \\
\hline Colombia & 1 & GDP does not 'Granger-cause' exports & $16.8^{* * *}$ \\
& \multirow{3}{*}{1} & Exports do not 'Granger-cause' GDP & 0.32 \\
Ecuador & 1 & GDP does not 'Granger-cause' exports & $23.6^{* * *}$ \\
& & Exports do not 'Granger-cause' GDP & 2.4 \\
\hline
\end{tabular}

Note: The asterisks indicate the rejection of the null hypothesis of the respective test (at 5\%). The value of the $\operatorname{VAR}(\mathrm{p})$ lag order was estimated in the same way as in Table 3.

Source: Own elaboration.

Table 4 presents the results of the Block Exogeneity Wald tests; the results for each country indicate the following:

1. Bolivia: Bidirectional causality exists; as such, the $\ln (E X P)$ variable Granger causes the $\ln (G D P)$ variable, and the $\ln (G D P)$ variable Granger causes the $\ln (E X P)$ variable.

2. Colombia: Unidirectional causality exists; the $\ln (G D P)$ variable Granger causes the $\ln (E X P)$ variable.

3. Ecuador: Unidirectional causality exists; the $\ln (G D P)$ variable Granger causes the $\ln (E X P)$ variable. 


\section{Discussion}

Considering the results obtained, it can be concluded that within the CAN framework, the growth hypothesis offered by the export-led model is only fulfilled in Bolivia and it is not unidirectional. Therefore, the CAN countries should not focus on economic policies that seek to boost the export sector as a foundational and priority sector of the economy. However, it cannot be ignored that the presence of cointegration in the economies of Bolivia, Colombia, and Ecuador indicates that the export and GDP variables behave in a coordinated manner over the long term.

This result aligns with the conclusions reached by Tang et al. (2015), in which they argue that the economies of Hong Kong, South Korea, Singapore, and Taiwan should not focus their growth policies exclusively on the promotion of the export sector.

Furthermore, this study shows that in Colombia and Ecuador, the behaviour of the GDP variable has causality on the behaviour of the export variable. A similar result was obtained by Gokmenoglu et al. (2015) for Costa Rica from 1980-2013. Their study produced a recommendation for Costa Rica to pursue an economic policy that promotes GDP growth and to move away from export promotion policies - a recommendation that applies to all the CAN countries.

According to these findings, it is clear that interventionist policies seeking to boost the export sector as a driver of economic growth are misguided. Even the study by Shafiullah et al. (2015), which did not reject the ELG hypothesis, recommended that Australian economic growth should not rely on exports because this model has caused regional concentrations of economic growth.

The economic policies of the CAN countries must consider the recommendations offered by Thomas (2011), discard the idea of collective growth based on export promotion, and instead think of an alternative "whereby export-led growth is replaced by a new paradigm: domestic demand-led growth" (Thomas, 2011. p. 10). 
Carvajal and López Camargo An Empirical Test of the Export-Led Model in the Member...

The suggestions presented in this study should not be ruled out by Peru, even though it was not possible to establish causality or ascertain the longterm relationship between the GDP and EXP variables for this country. The behaviour of these two variables should not be thought of as being "very far" from the behaviour demonstrated by the other CAN countries.

\section{References}

Comunidad Andina de Naciones. (2018). Reseña histórica. Retrieved on March 27, 2018. http://www.comunidadandina.org/Seccion.aspx?i $\mathrm{d}=195$ \&tipo=QU\&title=resena-historica

Comunidad Andina de Naciones. (2010). Estadisticas de la semana. Evolución del Producto Interno Bruto (PIB) por habitante de la Comunidad Andina de Naciones 1970-2010. http://intranet.comunidadandina.org/Docum entos/DEstadisticos/SGde365.pdf

Enders, W. (2003). Applied Econometric Time Series. Wiley.

Engle, R. Granger, W. (1987). Cointegration and error correction representation, estimation and testing. Econometrica 55 (2), 251-276. https://doi.org/10.2307/1913236

Gaviria Ríos, M. A. (2010). Apuntes de economía regional. Pereira: Universidad Católica Popular del Risaralda.

Gokmenoglu, K., Sehnaz, Z. \& Taspinar, N. (2015). The Export-Led Growth: A Case Study of Costa Rica. Procedia Economics and Finance 25, 471-477. https://doi.org/10.1016/S2212-5671(15)00759-5

Gonzalo, J. (1994). Five alternative methods of estimating long-run equilibrium relationships. Journal of Econometrics 60 (1-2), 203-233. https://doi.org/10.1016/0304-4076(94)90044-2

Granger, C. (1969). Investigating Causal Relations by Econometric Models and Cross-spectral Methods. Econometrica, 37(3), 424-438. https://doi. org/10.2307/1912791 
Jaunky, V. C. (2013). A cointegration and causality analysis of copper consumption and economic growth in rich countries. Resources Policy 38 (4), 628-639. https://doi.org/10.1016/j.resourpol.2013.10.001

Montero, R. (2013). Variables no estacionarias y cointegración [working paper]. Universidad de Granada.

Nguyen, H. (2011). Exports, Imports, FDI, and Economic Growth. Discussion papers in economics. Working Paper No. 11-03, 1-47.

Osterwald-Lenum, M. (1992). A Note with Quantiles of the Asymptotic Distribution of the Maximum Likelihood Cointegration Rank Test Statistic. Oxford Bulletin of Economics and Statistics 54(3), 461-472. https: //doi.org/10.1111/j.1468-0084.1992.tb00013.x

Thomas, P. (2011). The contradictions of export-led growth. Jerome Levy Economics Institute of Bard College, No. 119.

Regúlez, M. (2006). Ejemplo de análisis de cointegración con Gretl. Departamento de Economía Aplicada III [notes]. UPV-EHU.

Sant'Anna, L., Filomena, T. \& Caldeira, J. (2017). Index tracking and enhanced indexing using cointegration and correlation with endogenous portfolio selection. The Quarterly Review of Economics and Finance, 65, 146-157. https://doi.org/10.1016/j.qref.2016.08.008

Schlitzer, G. (1995). Testing the stationarity of economic time series: further Monte Carlo evidence. Ricerche Economiche 49 (2), 125-144. https: //doi.org/10.1016/0035-5054(95)90019-5

Shafiullah, M., Selvanathan, S. \& Naranpanawa, A. (2017). The role of export composition in export-led growth in Australia and its regions. Economic Analysis and Policy 53, 62-76 https://doi.org/10.1016/j.eap.2016.11.002

Tang, C. F., Lai, Y. \& Ozturk, I. (2015). How stable is the export-led growth hypothesis? Evidence from Asia’s Four Little Dragons. Economic Modelling 44, 229-235. https://doi.org/10.1016/j.econmod.2014.09. 022 